\title{
Structural adjustment and health
}

\author{
Consider the consequences for the least empowered
}

Copenhagen's world summit for social development has come and gone, ${ }^{1}$ but women and children continue to bear the brunt of socioeconomic adjustment and consequent ill health. Their burden is particularly poignant in sub-Saharan Africa, where indicators such as female literacy, maternal mortality, infant mortality, mortality among under $5 \mathrm{~s}$, and immunisation rates continue to stagnate or deteriorate. ${ }^{2}$ In Copenhagen some of the world's most powerful leaders discussed the social problems that afflict every country, "especially poverty, unemployment and social exclusion." ${ }^{34}$ Their declaration to target the causes of poverty, however, are unlikely to focus on the structural and institutional causes of poverty..$^{5-7}$

How can one impress on Africa's policymakers and the Western powers that encourage them that the money spent on arms would be better spent on educating women and providing basic health care? How can one impress on Africa's policymakers that it is their responsibility to encourage the preservation of family structures and to take measures to avoid conflict in the home and the community, thereby making life for our children, who are tomorrow's adults, more stable?

Throughout history, African women have stoically dealt with socioeconomic adjustment, struggling to ensure that as many of their offspring as possible survive their early years. But the cumulative impact of their struggle will probably result only in beleaguered survivors who, before the age of 5, are already in debt to the World Bank. Each year of their lives they unknowingly accumulate a larger debt, without hope of ever paying it off. ${ }^{8}$

Socioeconomic adjustment at the microlevel encompasses the myriad number of measures that individuals, families, or communities use when their economic environment changes as a result of war, injury, death, or general economic decline. These adjustments have been heavily influenced by policies at the macrolevel-for example, structural adjustment introduced by the International Monetary Fund and the World Bank. These programmes include currency devaluation and liberalising trade by increasing exports, decreasing imports, and increasing local access for foreign and transnational corporations. Government spending is cut by introducing user charges, withdrawing subsidies, privatisation, retrenching civil servants, and introducing wage restraints. ${ }^{8}$

Structural adjustment programmes require that food subsidies be cut at a time when agricultural productivity has already been hampered, in most African countries, by civil strife, famine, or drought. Adjustment measures further require the export of cash crops, which flood the international market and drive prices down. A fall in subsistence farming results from cash crop farming, leading to a poor diet for mothers and children.

Field observation shows continuing high or increased maternal, infant, and child mortality and morbidity as families cut household spending by delaying to seek treatment, if they seek treatment at all. ${ }^{9}$ Social services, along with ministries of health and education, are facing cuts in funding when, ironically, ministries of defence, internal and foreign affairs maintain high or increased levels of spending.

Adjustment policies ensure that governments in the developing world do not renege on their debt repayments, and accelerate towards a Western style, free market economy. This ideology is exported by countries that seek to open foreign markets, while continuing to protect their own. ${ }^{8}$ But literacy levels, school enrolment, managerial skills, information systems, and the empowerment of women in Africa are nowhere near high enough to sustain the mechanisms that would make a free market economy viable on a grand scale in Africa. To propagate a free market economy uniformly across Africa now can be to benefit only Western transnationals and power brokers and Africa's powerful urban elites. Unfortunately, it would be to the detriment of rural and urban poor people, whose cheap labour and continued unemployment fuel the free market economy, unless their education, incomes, and skills are improved as the fruits of economic growth are reaped.

\section{Civil strife}

Poverty is inexorably exerting a firmer grip on the populations of Africa, causing a migration mainly of males from the countryside to the cities. In the wake of this migration comes unemployment in the cities, robberies, violence, civil unrest, and HIV infection. As populations stratify further into the "haves" and "have nots," conflict brews. Throughout subSaharan Africa, governments have failed to reverse the state of almost continuous civil strife, as the continuing battles in Rwanda, Burundi, Somalia, and Liberia and the more "silent" wars in Chad, Sudan, and Angola can attest. Conflicts continue to rage in countries where there is no government to speak of, and which make the declarations of this year's world summit almost farcical. Women and children, who usually have no input into policy decisions at the macrolevel, make up 
most of the population who are displaced, raped, and psychologically traumatised by these conflicts and yet are concurrently expected to take care of those who are ill, injured, and dying, and to buffer the adverse socioeconomic effects of conflict.

\section{Feathered nests}

In the aftermath, sometimes even during these wars, African governments make arrangements with Western governments and banks to "structurally adjust" their debt repayment, or continue to trade their country's resources away, building economic empires both at home and abroad, while their populations slide further into poverty. Debts, which accumulate during the years of civil strife, even as they negotiate, stall social programmes that are cut at the expense of building a war machine. ${ }^{7}$

The effects of political insecurity and the growing debt burden, especially in sub-Saharan Africa, need to be brought centre stage in the aftermath of the world summit for social development. A cessation of hostilities and civil strife and managerially efficient government bureaucracies are the keys to successful economic development. Consequent rises in incomes, in turn, would lead to improved health.

Whatever paltry financial gains countries achieve, with or without adjustment, continue to be inadequately invested in education, transport, telecommunications, and industrialisation-the keys to development. Instead they are ploughed back into debt repayments rather than into the social sector, where the main recipients would be women and children.

Rigorous research examining any relation between structural adjustment and the fall in health indicators, especially of mothers and children, has so far been lacking. ${ }^{9}$ What does exist is largely anecdotal, and the World Bank and other agencies have felt justified in ignoring it. Nevertheless, structural adjustment programmes are often followed by civil unrest bordering on outright war as the social security net of the poor majority is eroded while the economic elite ride the storm.

Of course, governments in Africa should shoulder part of the blame for the fall in living standards and services in the social sector. Often they have not had sound economic policies in place before the International Monetary Fund and
World Bank offered their solutions. But both borrowers and lenders have the responsibility to offer viable solutions that take into account the political, economic, and sociocultural context of each country and the socioeconomic agenda of the government in place. African governments and regional bodies have to offer their own blunt analysis and solutions to the political and economic impasses that their countries face, including the potential negative effects of macrolevel policies, before Western governments and economic institutions offer theirs. ${ }^{56}$

Many of the long term effects of structural adjustment, already difficult to predict, will probably be noticed only when they have become irreversible. These effects include the migration of health workers ${ }^{10}$ and of the general population itself. Migrants, especially rural poor people displaced by civil war, who are often uneducated or not highly trained, end up competing with the population of the country they have migrated to for the few available jobs, depressing wages even further for that group, lowering the standard of living, or leading to unemployment, civil unrest, and violence.

To avert this depressing, scenario the global village requires those who wield economic power not to do so with total disregard for the political, socioeconomic, health, and cultural consequences to the recipients of major shifts in economic policies. These recipients are more often than not mothers and children, and they are the least empowered of all.

ANGELA M WAKHWEYA Associate editor

Medicine and Global Survival,

10 Brookline Place West,

Brookline, MA 02146,

USA

1 Logie D, Haines A. Copenhagen's challenge. BMF 1995;310:544-5.

2 United Nations Children's Fund. The state of the world's children. Report 1995. New York: Unicef, 1995.

3 United Nations. Draft outcome of the world summit for social development. Third PrepCom Session, 1627 fanuary 1995. New York: UN, 1995.

4 United Nations. Copenhagen declaration adopted by the world summit for social development, United Nations. Copenhagen declaration adopted by the world
Copenhagen, Denmark, 6-12 March 1995. Copenhagen: UN, 1995.

5 Mazrui AA. The Africans: a triple heritage. London: BBC Publications, 1986.

6 Museveni Yoweri K. What is Africa's problem? Kampala: NRM Publications, 1992.

7 Smyth F. Arms for Rwanda: blood money and geopolitics. Nation 1994 May 2:16-8.

8 George S. The debt boomerang: how third world debt harms us all. London: Pluto Press, 1992.

9 Costello A, Watson F, Woodward D. Human face or human facade? Adjustment and the health of mothers and children Parts I and II. London: Centre for International Child Health, Institute of Child Health, 1994.

10 Wakhweya A. Where are Uganda's doctors? Kampala: Unicef Kampala Office Library, 1992.

\title{
Is aid to developing countries hitting the spot?
}

\author{
We need better ways of evaluating the effects of aid programmes
}

Scenes of warfare in sub-Saharan Africa remind us of the impact of conflict on human life, but this is but one part of the "silent emergency" of poverty in developing countries. A report released by Oxfam last month reminds us that today one in four of the world's people live in a state of absolute want, unable to meet their basic needs. It calls for concerted action to eradicate poverty and establish new structures for human security. ${ }^{1}$

If sending Western aid to developing countries to alleviate poverty seems an exemplary response then the fall in the total sum allotted from $\$ 61$ bn in 1992 to $\$ 56$ bn in 1993 must be cause for concern. ${ }^{2}$ Although such figures are politically useful in lobbying for more, The Reality of Aid, published last month by non-government organisations, raises some more fundamental questions: Is aid hitting the spot? Are we sure that Western support and influence in developing countries ultimately alleviates poverty and helps development?

\section{The 1980s: development's biggest failure}

Ensuring economic development to reduce poverty generates little argument. Yet the 1980 s witnessed the biggest failure of development yet as developing countries were thrown into financial crisis through rising interest rates and falling commodity prices. The response-structural adjustment-was expected to improve growth and help poor people, yet evidence that these arrangements make poor people worse off is compelling. ${ }^{34}$ After 15 years' experience 